\title{
The impact of the proliferation of the Israeli products on the performance, sustainability and development of the Palestinian products at the local market
}

Asri Ahmad Abdalwahab Sammoudi

Arab American University, Palestine

\begin{abstract}
Keywords
Competition, product quality, Palestine market, Israeli market.
\end{abstract}

\begin{abstract}
This paper examines the influence of various variables on competing the Israeli products at the Palestinian market. These variables are (competition for quality, corporate management practices, procedures and laws, update and development, government policies and procedures and follow-up and evaluation). A survey has been conducted to examine the hypotheses of this paper. The population consists of directors of organizations, dealers, business owners, government employees, marketing managers, workers and customers. 500 questionnaires were distributed to the targeted respondents in Palestine using the random sample. 378 questionnaires were returned which represents $75.6 \%$ of the distributed sample. The finding of this paper are: (1) the current practices of the follow-up and evaluation of Palestinian products have a negative competitive impact (2) there is a positive role of the administrative practices of the Palestinian companies on competing the Israeli product. (3) there is a positive role of the quality of Palestinian product on competing the Israeli product. (4) there is no role of the current Palestinian procedures and laws on competing the Israeli product. (5) there is a positive role of updating and developing the Palestinian product to compete the Israeli product. (6) there is a negative role of the policies and procedures of the Palestinian government on competing the Israeli product. Based on the previous findings, this paper suggests the following recommendations: (1) the Palestinian producer should increase the quality of Palestinian products. (2) the current Palestinian procedures and laws that are related to the competition should be developed to meet the requirements of competition. (3) the Palestinian government must reform its competition policies and procedures. (4) the current practices of the follow-up and evaluation of Palestinian products should be updated.
\end{abstract}

Corresponding author: Asri Ahmad Abdalwahab Sammoudi

Email addresses for the corresponding author: asri.sammudi@aaup.edu

First submission received: 13 th June 2019

Revised submission received: $2^{\text {th }}$ August 2019

Accepted: 14 $4^{\text {th }}$ September 2019

\section{Introduction}

There is no doubt that competition among organizations is a fundamental constituent in economy and offers great benefits. It is considered as a leading motive in improving economic growth and in the development of products quality, increasing their quality and lowering their prices (Dasgupta et al, 2009; Wen-Cheng et al, 2011). Thus, it's worth mentioning that the increasing number of suppliers of various products, goods or services is a necessity for improving and developing products as the result of the competition, which is a fundamental principle in the market economy (Petison and Johri, 2006; Hamel \& Green, 2007; Shapiro 2012).

There are a set of requirements needed for getting effective benefits of competition. These requirements, for instance, the availability of an appropriate economic climate that helps to create conducive environment for business; including elements such as industrial and service infrastructure and financial and banking facilities. In addition to the availability of government support in various fields such as tax benefits, customs and financial support in order to achieve a healthy competitive environment that serves the consumer. Add to this the competitive opportunity in foreign markets as a direct result of the development and improvement of local products (Dyer \& Singh, 1998; Romero \& Martinez-Roman, 2012). 
In this paper, the researcher aims at examining and exposing the competitive reality between the Israeli and Palestinian products, the different circumstances surrounding them, and the facts that highlight the difficult situation experienced by Palestinian companies as a result of the Israeli companies' appropriation of Palestinian markets. This is an extension of the reality of Israeli control over Palestinian capabilities. The movement of various production elements of the captive Palestinian economy which suffers from a lack of the economic fundamentals that enable it to rise and develop. It's widely known that the Israeli side has an absolute control over the crossings, borders, ports, airports, and the accompanying checks of imports and exports, goods or services. This means that there is a full control over the movement of goods and labor, the whole means of production and operations in both directions. As a result, these obstacles altogether weakness the Palestinian economy and makes it fragile and dependent on the Israeli one. Unfortunately, this difficult reality and special circumstances created two types of economies competing in one market. Each one belongs to a completely different economic system, political and legal environment in which this competition occurs unilaterally. This means the Israeli products compete the Palestinian ones in Palestine's own markets unilaterally. In other words, (PA) are not allowed to sell or market their own products at the Israeli market. The Israeli side accept small quantities and varieties of the Palestinian products to enter its borders that are completely controlled by the them.

In consequence, the researcher introduces a vital issue titled the effect of the increase of Israeli products in the Palestinian market on the performance, continuity and development of the Palestinian national products. In fact, Israeli companies take advantage of the Palestinian markets easily which is considered as an important part in supporting the Israeli economy. Despite the fact that the Israeli domestic production reaches about $\$ 291.4$ billion in 2013 with $2 \%$ yearly growth; the Palestinian side and in the same year reaches (9.7) billion dollars in which mostly comes in the form of international aid (World Bank, 2013).

To add insult to injury, the Palestinian companies are facing great challenges and obstacles. They, for instance, face companies that are well-qualified and have the competitive and financial power and the government support. In contrast, the Palestinian companies rely basically on individual efforts and with small capital. There are also some volatile foreign investments, but due to many financial and tax consequences and unstable economic and political conditions altogether led to an increase in their vulnerability and sometimes increase in their competitiveness and sustainability.

Thus, to the best of my believe and knowledge in respect to the subject of this study and my choice of it in terms of reviving the Palestinian economic, social, national and consumer awareness by revealing the danger of flooding the Palestinian markets with Israeli goods and the consequent significant economic damage that affect many different economic sectors which depend on the Palestinian productive sector. This awareness participates in the development and sustainability of the Palestinian local products. Unfortunately, compared to the Israeli ones, the Palestinian products are not able to compete with the Israeli one due to their quality, industrial and technological capabilities, financial facilities and government support. In addition to the impact on the Palestinian consumer and consumer loyalty who is also an easy victim as a result of the availability of these products in the markets in large quantities and at prices that are often less than the Palestinian counterparts offer. However, to achieve the desired objectives of this paper, a survey study is conducted.

\section{Problem Statement}

This paper examines the impact of the availability of the Israeli products in the Palestinian market on the performance, continuity and development of Palestinian economy. Palestinian companies find themselves in a challenge. In fact, they face companies with competitive and financial strength and large government support; whereas the Palestinian companies rely on individual efforts and relatively small capital, and some volatile foreign investments due to many financial and tax implications and unstable economic and political conditions. This reality increases the vulnerability more than the weakness of competitiveness and continuity. As a result the researcher examines this issue from various aspects in order to answer as far as possible this important problem. The problem of the study is clarified through the following questions:

1. What is the competitive effect of the Palestinian products quality on Israeli products? 
2. What is the impact of the Palestinian companies' administrative practices on competing Israeli products?

3. What is the impact of the Palestinian procedures and laws on competing Israeli products?

4. What is the impact of developing and modernizing Palestinian products on competing Israeli products?

5. What is the impact of the policies and procedures of the Palestinian government on competing Israeli products?

6. What is the impact of the follow-up and evaluation of Palestinian products on competing Israeli products?

\section{Objectives}

This paper comes to achieve the following objectives:

1. Exploring the impact of increasing the Israeli goods at the Palestinian market on the local products.

2. Explaining the competitive situation between some Palestinian and Israeli products.

3. Conduct a Poll targets Palestinian consumers' opinions on boycotting the Israeli products and encouraging national industry.

4. Clarifying the government's role in controlling and regulating the entry of the Israeli products into the Palestinian market.

5. Exploring the laws and procedures implemented by the Palestinian government in terms of supporting the Palestinian institutions in facing the Israeli companies.

6. Recognizing the reality of the conditions experienced by Palestinian companies in facing the Israeli companies.

\section{Literatures Review}

The previous studies agree that the competition strategy leads to achieving high level of growth in revenues (Muslem, 2005; Petison and Johri, 2006; Hamel \& Green, 2007; Shapiro 2012; Svarova and Vrchota, 2014). In Palestine, the previous studies show that the restrictions that enforced by Israel have influence on completion (Muslem, 2005; Al-Natshi, 2013). The following is a presentation of some previous literatures:

Na'eem, (2017) aims at determining the role of social networks in economic behavior and orientation towards buying the national product in Palestine. The researcher reached the following findings: 1 . Social networks have an important role in building a positive attitude towards the national product and knowing the national companies topped by Facebook. 2. 78.7\% of the study sample are most interested in quality when buying. 3. The proportion of those who prefer national food products reached $69 \%$, mostly residents of border areas, compared to $31 \%$ of the sample of the study who prefer the occupation products, mostly from Gaza City. 4. The products of the occupation enjoy confidence even among those who boycott it; whereas only $6 \%$ of the sample do not trust the Israeli products.

Hana (2013) In today's highly competitive environment the goal of each organization is to defeat competition and win new customers. Individuals who are holders of knowledge represent a tool for the generation of innovations. Thanks to their personal creativity, their knowledge, skills and abilities it is possible to generate new innovative ideas that will help organizations to achieve a competitive advantage. The aim of the article is to present the findings of a survey targeted at innovations and to identify knowledge as an important element in the process of innovations. Primary data were obtained through a questionnaire survey carried out in organizations in the Czech Republic and evaluated using the tools of descriptive statistics and also the methods of comparison, induction, deduction and synthesis were applied. One of the conclusions of the article is that organizations find it important to innovate and support an innovative culture. Knowledge too is very significant in the innovation process since it represents not only important input, but also output of the transformation process.

Svarova and Vrchota (2014) shows that the current environment with growing interdependence between the markets and the rapid increasing in competition, it is more difficult to maintain current enterprise market position. It is more and more important to correctly select companies' strategy, because as mentioned by Kotler: "if the company has the same strategy as the competitors, it actually does not have a strategy. For these reasons it is necessary for the company to base this strategy on their own market 
position and build on their distinctive competitive advantage. Al-Natshi (2013) demonstrates the reasons behind enforcing the Palestinian importer to use an Israeli intermediary to indirectly import from the international markets instead of direct importing. On the first hand, the paper concluded that the main reasons for indirection the Palestinian importers to the Israeli markets are related to the difficulty of noncustom Israeli restrictions imposed on the Palestinian importer. On the second hand, the absence of independent Palestinian custom areas which increases imposing costs and exposing goods to theft and damage. In addition, some reasons are related to considering the Palestinian market as a part of the Israeli trade market by some international markets. Mainly for political reasons which prevent the Palestinian market from independently having international agencies.

Wen-Cheng et al, (2011) shows that the internal sources of competitive advantage cover wide range of areas. The important competitive advantages behind an organization are not merely determined by its external factors. The internal sources of competitive advantage of a firm have been considered as crucial factors to success. The research looks at the extensive literature in relation to competitive advantage. The formation of main theories in literature review was illustrated by the concepts of competitive advantages through proper management action when managing the structure, process, culture and people of an organization. Therefore, the aim of competitive advantage recognition is connect with resources, capabilities and core competencies of the organization.

Muslem (2005) indicates that the ever-broader circulation of information and activities regarding the Palestinian movement for boycott, divestment and sanctions (BDS), through such media as BDS News has emphasized its connection and resemblance to the South African experience. This made it vitally important to understand the local and international context in which the boycott emerged and developed as a tool of resistance. At the same time, one needs to relate this popular and civic struggle to more official elements in the national struggle, and then to identify the extent to which the BDS movement has evoked responses at the Arab and international levels; again setting this analysis against the background of the South African anti-apartheid movement.

The abovementioned discussion motivates me to investigate the impact of the proliferation of the Israeli products on the performance, sustainability and development of the Palestinian products at the local market. This paper relies on the descriptive-analytical approach by using concrete questionnaire that design to explore this issue from the reality of Palestine. The previous studies did not give concrete outcomes regarding this issue.

\section{The Hypotheses}

This paper comes to examine the following six hypotheses:

$\mathrm{H}_{\mathrm{O} 1}$ : There is no competitive impact of the Palestinian products quality on the Israeli products.

$\mathrm{H}_{\mathrm{O} 2}$ : The Palestinian companies' administrative practices have no competitive impact on the Israeli products.

$\mathrm{H}_{\mathrm{O} 3}$ : The current Palestinian procedures and laws has no competitive impact on the Israeli products.

$\mathrm{H}_{\mathrm{O} 4}$ : The Palestinian companies' procedures of developing and updating their products have no impact on competing the Israeli products.

$\mathrm{H}_{\mathrm{O} 5}$ : The adopted policies and procedures by the Palestinian government have no competitive impact on the Israeli products.

$\mathrm{H}_{\mathrm{O} 6}$ : There is no impact of the follow-up and evaluation of Palestinian the products on competing the Israeli products.

\section{Methodology}

This paper relies on the analytical-descriptive approach. Thus, the study tool (the questionnaire), verifying its validity, and its stability have been designed in accordance with its goals to be distributed to the targeted respondents. This paper also comes to shed the light on the increasing spread of the Israeli goods in the Palestinian markets. As a result, it explores the factors that lead to increase the competitive ability of the Palestinian products. the population of this paper consists of directors of organizations, dealers, business owners, government employees, marketing managers, workers and customers. 500 questionnaires were distributed to the respondents in Palestine using the random sample. 378 questionnaires were returned which represents $75.6 \%$ of the distributed sample. The questionnaire 
consists of six dimensions (competition for quality, corporate management practices, procedures and laws, update and development, government policies and procedures, and follow-up and evaluation) that are needed to motivate the competition position of Palestinian products. The five Likert scale was used as follows: (strongly agree $=5$, agree $=4$, neutral $=3$, disagree $=2$, and strongly disagree $=1$ ). The questionnaire has been refereed by five professors of business administration. The Cronbach's alpha test is used for examining the internal reliability of the questionnaire. Consequently, (Table 1) displays the results of this test.

Table (1) The Results of Cronbach's Alpha Test

\begin{tabular}{|l|l|l|}
\hline Variable Name & Items Number & Cronbach's Alpha \\
\hline Competition for Quality & 5 & 0.811 \\
\hline Corporate Management Practices & 5 & 0.880 \\
\hline Procedures and Laws & 5 & 0.843 \\
\hline Update and Development & 5 & 0.783 \\
\hline Government Policies and Procedures & 5 & 0.809 \\
\hline Follow-up and Evaluation & 5 & 0.768 \\
\hline All Dimensions & 30 & 0.886 \\
\hline
\end{tabular}

Cronbach's Alpha is very often used as a measure of internal consistency (scale reliability). As well, Cronbach's Alpha above 0.70 indicates very high degree of internal consistency (Taber, 2018). Table 1 shows that the values of Alpha are greater than $70 \%$ which indicates that there is internal consistency of the questions tool. This result enables us to generalize the consequences of this paper.

Table 2: Descriptive Statistics of the Demographic Variables

\begin{tabular}{|c|c|c|c|}
\hline Variable & Variable Possibilities & Frequencies & Percent \% \\
\hline \multirow{3}{*}{ Gender } & Male & 277 & 73.3 \\
\hline & Female & 101 & 26.7 \\
\hline & Sum & 378 & 100 \\
\hline \multirow{6}{*}{ Age } & From 1 to 30 Years & 74 & 19.6 \\
\hline & From 31 to 40 Years & 151 & 39.9 \\
\hline & From 41 to 50 Years & 74 & 19.6 \\
\hline & From 51 to 60 Years & 68 & 18.0 \\
\hline & Above 60 Years & 11 & 2.9 \\
\hline & Sum & 378 & 100 \\
\hline \multirow{4}{*}{ Marital status } & Married & 308 & 81.5 \\
\hline & Single & 65 & 17.2 \\
\hline & Divorced & 5 & 1.3 \\
\hline & Sum & 378 & 100 \\
\hline \multirow{5}{*}{ Education } & Secondary School or Below & 111 & 29.4 \\
\hline & Diploma & 48 & 12.7 \\
\hline & Bachelor & 209 & 55.3 \\
\hline & Master & 10 & 2.6 \\
\hline & Sum & 378 & 100 \\
\hline \multirow{4}{*}{ Place of Residence } & Village & 179 & 47.4 \\
\hline & Town & 167 & 44.2 \\
\hline & Camp & 32 & 8.5 \\
\hline & Sum & 378 & 100 \\
\hline \multirow{8}{*}{ Job Title } & Director of Organization & 10 & 2.6 \\
\hline & Dealer & 99 & 26.2 \\
\hline & Business Owner & 68 & 18.0 \\
\hline & Government Employee & 38 & 10.1 \\
\hline & Marketing Manager & 58 & 15.3 \\
\hline & Worker & 42 & 11.1 \\
\hline & Customer & 63 & 16.7 \\
\hline & Sum & 378 & 100 \\
\hline
\end{tabular}

Table (2) illustrates the descriptive statistics of the demographic variables that clarify the characteristics of the study sample. Table 2 shows that $73.3 \%$ of the respondents are males and 26.7 are 
females. Table 2 also demonstrates that the respondent's age comes as the following: $19.6 \%$ of the respondents are from 1 to 30 years, $39.9 \%$ from 31 to 40 years, $19.6 \%$ from 41 to 50 years, $18.0 \%$ from 51 to 60 years, and $2.9 \%$ Above 60 Years. Table 4 shows that $81.5 \%$ of the respondents are married, $17.2 \%$ are single, and $1.3 \%$ are divorced. Also, table 2 shows that $29.4 \%$ of the respondents are secondary school or below, $12.7 \%$ diploma degree holders, $55.3 \%$ bachelor's degree holders and $2.6 \%$ hold a master's degree. Furthermore, table 2 demonstrates that the respondent's place of residence comes as follows: $47.4 \%$ of the respondents are living in village, 44.2 are living in towns, and $8.5 \%$ are living in camps. Finally, Table 2 pointed out to the respondent's job title as the following: $2.6 \%$ of them are directors of organizations, $26.2 \%$ are dealers, $18.0 \%$ are business owners, $10.1 \%$ are government employees, $15.3 \%$ are marketing managers, $11.1 \%$ are workers, and $16.7 \%$ are customer. The results indicate that the sample of this paper is appropriate to generalize its findings.

\section{The Findings}

This section examines the hypotheses of this paper. Presented below are the findings of the six hypotheses.

The Results of the First Hypothesis

$\mathrm{H}_{\mathrm{O} 1}$ : There is no competitive impact of the Palestinian products quality on the Israeli products.

Table 3 shows that the quality level of the Palestinian products has positive competitive impact on the Israeli products. The mean of "competition for quality" variable is 4.05 which indicates a high impact of this variable on competing at Israeli market. The value of $\mathrm{T}$ (one sample t-test at test value $=3$ ) is 41.76 , and statistically is significant at 0.05 . This result ensures the positive completive role of the Palestinian products quality on competing the Israeli product.

Table 3: Statistics for Describing the Impact of the Quality of the Palestinian Products on Competing Israeli Products

\begin{tabular}{|c|c|c|c|c|c|c|c|c|c|}
\hline$\#$ & Question & $\begin{array}{l}\text { Strongly } \\
\text { Agree }\end{array}$ & Agree & Neutral & Disagree & $\begin{array}{l}\text { Strongly } \\
\text { Disagree }\end{array}$ & Mean & T Value & Alpha \\
\hline 1 & $\begin{array}{l}\text { Israeli products are } \\
\text { heavily deployed in } \\
\text { Palestinian markets. }\end{array}$ & $\begin{array}{l}244 \\
64.6 \%\end{array}$ & $\begin{array}{l}123 \\
32.5 \%\end{array}$ & $\begin{array}{l}0 \\
0.0 \%\end{array}$ & $\begin{array}{l}11 \\
2.9 \%\end{array}$ & $\begin{array}{l}0 \\
0.0 \%\end{array}$ & 4.59 & 47.73 ** & 0.00 \\
\hline 2 & $\begin{array}{l}\text { Palestinian consumers } \\
\text { prefer the Israeli } \\
\text { product compared to } \\
\text { the Palestinian ones. }\end{array}$ & $\begin{array}{l}207 \\
54.8 \%\end{array}$ & $\begin{array}{l}150 \\
39.7 \%\end{array}$ & $\begin{array}{l}0 \\
0.0 \%\end{array}$ & $\begin{array}{l}21 \\
5.6 \%\end{array}$ & $\begin{array}{l}0 \\
0.0 \%\end{array}$ & 4.44 & $36.65 * *$ & 0.00 \\
\hline 3 & $\begin{array}{l}\text { The Israeli product } \\
\text { has better quality than } \\
\text { the Palestinian } \\
\text { product. }\end{array}$ & $\begin{array}{l}202 \\
53.4 \%\end{array}$ & $\begin{array}{l}161 \\
42.6 \%\end{array}$ & $\begin{array}{l}0 \\
0.0 \%\end{array}$ & $\begin{array}{l}15 \\
4.0 \%\end{array}$ & $\begin{array}{l}0 \\
0.0 \%\end{array}$ & 4.46 & 40.52 ** & 0.00 \\
\hline 4 & $\begin{array}{l}\text { The prices of the } \\
\text { Israeli products are } \\
\text { higher than the prices } \\
\text { of the local products. }\end{array}$ & $\begin{array}{l}179 \\
47.4 \%\end{array}$ & $\begin{array}{l}122 \\
32.3 \%\end{array}$ & $\begin{array}{l}0 \\
0.0 \%\end{array}$ & $\begin{array}{l}77 \\
20.4 \%\end{array}$ & $\begin{array}{l}0 \\
0.0 \%\end{array}$ & 4.07 & $18.27 * *$ & 0.00 \\
\hline 5 & $\begin{array}{l}\text { The Palestinian } \\
\text { product has high } \\
\text { quality. }\end{array}$ & $\begin{array}{l}25 \\
6.6 \%\end{array}$ & $\begin{array}{l}69 \\
18.3 \%\end{array}$ & $\begin{array}{l}115 \\
30.4 \%\end{array}$ & $\begin{array}{l}164 \\
43.4 \%\end{array}$ & $\begin{array}{l}5 \\
1.3 \%\end{array}$ & 2.85 & $-2.96 * *$ & 0.01 \\
\hline & npetition for Quality & $\begin{array}{l}171 \\
45.3 \%\end{array}$ & $\begin{array}{l}125 \\
33.1 \%\end{array}$ & $\begin{array}{l}23 \\
6.1 \% \\
\end{array}$ & $\begin{array}{l}58 \\
15.3 \%\end{array}$ & $\begin{array}{l}1 \\
0.2 \%\end{array}$ & 4.08 & $41.76^{* *}$ & 0.00 \\
\hline
\end{tabular}

** Significant at 0.01, * significant at 0.05 .

The Results of the Second Hypothesis

$\mathrm{H}_{\mathrm{O} 2}$ : The Palestinian companies' administrative practices has no competitive impact on the Israeli products.

Table 4 shows that the administrative practices of the Palestinian companies have a positive impact on competing the Israeli products. The mean of "the administrative practices of Palestinian companies" variable is 3.17. This result indicates the high impact of this variable on competing at the Israeli market. The value of $\mathrm{T}$ (one sample t-test at test value $=3$ ) is 4.09 and statistically is significant at 0.05. This result ensures the positive role of the administrative practices of Palestinian companies on competing the Israeli products. 
Table 4: Statistics for Describing the Impact of the Administrative Practices of Palestinian Companies on Competing the Israeli Products

\begin{tabular}{|c|c|c|c|c|c|c|c|c|c|}
\hline$\#$ & Question & $\begin{array}{l}\text { Strongly } \\
\text { Agree }\end{array}$ & Agree & Neutral & Disagree & $\begin{array}{l}\text { Strongly } \\
\text { Disagree }\end{array}$ & Mean & $\begin{array}{l}\mathrm{T} \\
\text { Value }\end{array}$ & Alpha \\
\hline 6 & $\begin{array}{l}\text { There is follow-up and } \\
\text { inspection by the } \\
\text { competent institutions } \\
\text { regarding the quality and } \\
\text { validity of the Israeli } \\
\text { products. }\end{array}$ & $\begin{array}{l}25 \\
6.6 \%\end{array}$ & $\begin{array}{l}178 \\
47.1 \%\end{array}$ & $\begin{array}{l}91 \\
24.1 \%\end{array}$ & $\begin{array}{l}84 \\
22.2 \%\end{array}$ & $\begin{array}{l}0 \\
0.0 \%\end{array}$ & 3.38 & $8.21^{* *}$ & 0.00 \\
\hline 7 & $\begin{array}{l}\text { There are laws and } \\
\text { procedures to protect } \\
\text { Palestinian products. }\end{array}$ & $\begin{array}{l}25 \\
6.6 \%\end{array}$ & $\begin{array}{l}147 \\
38.9 \%\end{array}$ & $\begin{array}{l}74 \\
19.6 \%\end{array}$ & $\begin{array}{l}132 \\
34.9 \%\end{array}$ & $\begin{array}{l}0 \\
0.0 \%\end{array}$ & 3.17 & $\begin{array}{l}3.39 \\
* *\end{array}$ & 0.00 \\
\hline 8 & $\begin{array}{l}\text { There is effective control } \\
\text { procedures to limit the } \\
\text { entry of the Israeli } \\
\text { products into Palestinian } \\
\text { markets. }\end{array}$ & $\begin{array}{l}25 \\
6.6 \%\end{array}$ & $\begin{array}{l}158 \\
41.8 \%\end{array}$ & $\begin{array}{l}99 \\
26.2 \%\end{array}$ & $\begin{array}{l}96 \\
25.4 \%\end{array}$ & $\begin{array}{l}0 \\
0.0 \%\end{array}$ & 3.30 & $\begin{array}{l}6.25 \\
* *\end{array}$ & 0.00 \\
\hline 9 & $\begin{array}{l}\text { There are governmental } \\
\text { facilities in the law, } \\
\text { procedures and taxes to } \\
\text { protect and encourage } \\
\text { Palestinian industries. }\end{array}$ & $\begin{array}{l}15 \\
4 \%\end{array}$ & $\begin{array}{l}138 \\
36.5 \%\end{array}$ & $\begin{array}{l}87 \\
23 \%\end{array}$ & $\begin{array}{l}122 \\
32.3 \%\end{array}$ & $\begin{array}{l}16 \\
4.2 \%\end{array}$ & 3.04 & 0.714 & 0.48 \\
\hline 10 & $\begin{array}{l}\text { Palestinian laws are } \\
\text { sufficient to protect the } \\
\text { local products. }\end{array}$ & $\begin{array}{l}15 \\
4 \%\end{array}$ & $\begin{array}{l}131 \\
34.7 \%\end{array}$ & $\begin{array}{l}63 \\
16.7 \%\end{array}$ & $\begin{array}{l}159 \\
42.1 \%\end{array}$ & $\begin{array}{l}10 \\
2.6 \%\end{array}$ & 2.95 & -0.911 & 0.36 \\
\hline \multicolumn{2}{|c|}{$\begin{array}{ll}\text { Administrative Practices of } \\
\text { Palestinian Companies }\end{array}$} & $\begin{array}{ll}21 \\
5.5 \%\end{array}$ & $\begin{array}{l}150 \\
39.7 \%\end{array}$ & $\begin{array}{l}83 \\
22\end{array}$ & $\begin{array}{l}119 \\
31.5 \%\end{array}$ & $\begin{array}{l}5 \\
1.3 \%\end{array}$ & 3.17 & $\begin{array}{l}4.09 \\
* *\end{array}$ & 0.00 \\
\hline
\end{tabular}

** Significant at 0.01, * significant at 0.05 .

The Results of the Third Hypothesis

$\mathrm{H}_{\mathrm{O} 3}$ : The current Palestinian procedures and laws has no competitive impact on the Israeli products.

Table 5 shows that the Palestinian procedures and laws have no impact on competing the Israeli products. The mean of "Palestinian procedures and laws" variable is 2.41 which indicates the that there is no impact of this variable on competing at the Israeli market. The value of $\mathrm{T}$ (one sample $\mathrm{t}$-test at test value =3) is -13.4 and statistically is insignificant. This result ensures that there is no role of the current Palestinian procedures and laws on competing the Israeli product.

Table 5: Statistics for Describing the Impact of the Palestinian Procedures and Laws on Competing the Israeli Products

\begin{tabular}{|c|c|c|c|c|c|c|c|c|c|}
\hline \# & Question & $\begin{array}{l}\text { Strongly } \\
\text { Agree }\end{array}$ & Agree & Neutral & Disagree & $\begin{array}{l}\text { Strongly } \\
\text { Disagree }\end{array}$ & Mean & $\begin{array}{l}\mathrm{T} \\
\text { Value } \\
\end{array}$ & Alpha \\
\hline 11 & $\begin{array}{l}\text { There is follow-up and } \\
\text { inspection by the competent } \\
\text { institutions regarding the } \\
\text { quality and validity of the Israeli } \\
\text { products. }\end{array}$ & $\begin{array}{l}11 \\
\% 2.9\end{array}$ & $\begin{array}{l}152 \\
40.2 \%\end{array}$ & $\begin{array}{l}48 \\
12.7 \%\end{array}$ & $\begin{array}{l}157 \\
41.5 \%\end{array}$ & $\begin{array}{l}10 \\
2.6 \%\end{array}$ & 2.95 & -0.91 & 0.07 \\
\hline 12 & $\begin{array}{l}\text { There are laws and procedures } \\
\text { to protect Palestinian products. }\end{array}$ & $\begin{array}{ll}11 \\
2.9 \% \\
\end{array}$ & $\begin{array}{ll}105 \\
27.8 \% \\
\end{array}$ & $\begin{array}{ll}65 \\
17.2 \% \\
\end{array}$ & $\begin{array}{ll}176 \\
46.6 \% \\
\end{array}$ & $\begin{array}{ll}21 \\
5.6 \%\end{array}$ & 2.99 & -0.15 & 0.11 \\
\hline 13 & $\begin{array}{l}\text { There is an effective control and } \\
\text { procedures against the entry of } \\
\text { the Israeli products into } \\
\text { Palestinian markets. }\end{array}$ & $\begin{array}{l}0 \\
0.0 \%\end{array}$ & $\begin{array}{l}63 \\
16.7 \%\end{array}$ & $\begin{array}{l}64 \\
16.9 \%\end{array}$ & $\begin{array}{l}219 \\
57.9 \%\end{array}$ & $\begin{array}{l}32 \\
8.5 \%\end{array}$ & 2.76 & -4.62 & -0.14 \\
\hline 14 & $\begin{array}{l}\text { There are governmental facilities } \\
\text { in laws, procedures and taxes to } \\
\text { protect and encourage } \\
\text { Palestinian industry. }\end{array}$ & $\begin{array}{l}0 \\
0.0 \%\end{array}$ & $\begin{array}{l}63 \\
16.7 \%\end{array}$ & $\begin{array}{l}58 \\
15.3 \%\end{array}$ & $\begin{array}{l}235 \\
62.2 \%\end{array}$ & $\begin{array}{l}22 \\
5.8 \%\end{array}$ & 2.42 & -13.08 & -0.49 \\
\hline 15 & $\begin{array}{l}\text { Palestinian laws are enough to } \\
\text { protect the local product. }\end{array}$ & $\begin{array}{ll}11 \\
2.9 \%\end{array}$ & $\begin{array}{l}36 \\
9.5 \%\end{array}$ & $\begin{array}{l}73 \\
19.3 \%\end{array}$ & $\begin{array}{l}236 \\
62.4 \%\end{array}$ & $\begin{array}{l}22 \\
5.8 \%\end{array}$ & 2.43 & -13.31 & -0.48 \\
\hline \multicolumn{2}{|c|}{ Procedures and Laws } & $\begin{array}{l}7 \\
1.8 \%\end{array}$ & $\begin{array}{l}84 \\
22 \%\end{array}$ & $\begin{array}{l}61 \\
16\end{array}$ & $\begin{array}{l}205 \\
54.2 \%\end{array}$ & $\begin{array}{l}21 \\
5.6 \%\end{array}$ & 2.41 & -13.40 & -0.50 \\
\hline
\end{tabular}

** Significant at $0.01,{ }^{*}$ significant at 0.05 . 
The Results of the Fourth Hypothesis

$\mathrm{H}_{\mathrm{O} 4}$ : The Palestinian companies' procedures of developing and updating their products have no impact on competing the Israeli products.

Table 6 shows that the process of updating and developing the Palestinian product has a positive impact on competing the Israeli products. The mean of "updating and developing the Palestinian products" variable is 3.24 which indicates the that there is an impact of this variable on competing at the Israeli market. The value of $\mathrm{T}$ (one sample t-test at test value $=3$ ) is 6.01 and statistically is significant. This result ensures that there is a positive role of updating and developing the Palestinian products on competing the Israeli products.

Table 6: Statistics for Describing the Impact of Updating and Developing the Palestinian Products on Competing the Israeli Products

\begin{tabular}{|c|c|c|c|c|c|c|c|c|c|}
\hline \# & Question & $\begin{array}{l}\text { Strongly } \\
\text { Agree }\end{array}$ & Agree & Neutral & Disagree & $\begin{array}{l}\text { Strongly } \\
\text { Disagree }\end{array}$ & Mean & $\begin{array}{l}\mathrm{T} \\
\text { Value } \\
\end{array}$ & Alpha \\
\hline 16 & $\begin{array}{l}\text { There are sufficient efforts to } \\
\text { modernize and develop the } \\
\text { Palestinian product. }\end{array}$ & $\begin{array}{l}27 \\
7.1 \%\end{array}$ & $\begin{array}{l}120 \\
31.7 \%\end{array}$ & $\begin{array}{l}110 \\
29.1 \%\end{array}$ & $\begin{array}{l}121 \\
32 \%\end{array}$ & $\begin{array}{l}0 \\
0.0 \%\end{array}$ & 3.14 & $2.86^{* *}$ & 0.00 \\
\hline 17 & $\begin{array}{l}\text { The Palestinian product is } \\
\text { modern and can compete the } \\
\text { Israeli product. }\end{array}$ & $\begin{array}{l}27 \\
7.1 \%\end{array}$ & $\begin{array}{l}84 \\
22.2 \%\end{array}$ & $\begin{array}{l}79 \\
20.9 \%\end{array}$ & $\begin{array}{l}168 \\
44.4 \%\end{array}$ & $\begin{array}{l}20 \\
5.3 \%\end{array}$ & 2.81 & $\begin{array}{l}-3.38 \\
* *\end{array}$ & 0.00 \\
\hline 18 & $\begin{array}{l}\text { The Israeli product shapes an } \\
\text { obstacle to develop the } \\
\text { Palestinian product. }\end{array}$ & $\begin{array}{l}79 \\
20.9 \%\end{array}$ & $\begin{array}{l}130 \\
34.4 \%\end{array}$ & $\begin{array}{l}38 \\
10.1 \%\end{array}$ & $\begin{array}{l}121 \\
32 \%\end{array}$ & $\begin{array}{l}10 \\
2.6 \%\end{array}$ & 3.39 & $6.26 * *$ & 0.00 \\
\hline 19 & $\begin{array}{l}\text { The Israeli product is having } \\
\text { better quality and } \\
\text { sophistication than the } \\
\text { Palestinian product. }\end{array}$ & $\begin{array}{l}57 \\
15.1 \%\end{array}$ & $\begin{array}{l}131 \\
34.7 \%\end{array}$ & $\begin{array}{l}95 \\
25.1 \%\end{array}$ & $\begin{array}{l}85 \\
22.5 \%\end{array}$ & $\begin{array}{l}10 \\
2.6 \%\end{array}$ & 3.37 & $\begin{array}{l}6.72 \\
* *\end{array}$ & 0.00 \\
\hline 20 & $\begin{array}{l}\text { There are challenges faced by } \\
\text { the Palestinian companies in } \\
\text { R \& D. }\end{array}$ & $\begin{array}{l}57 \\
15.1 \%\end{array}$ & $\begin{array}{l}162 \\
42.9 \%\end{array}$ & $\begin{array}{l}68 \\
18 \%\end{array}$ & $\begin{array}{l}91 \\
24.1 \%\end{array}$ & $\begin{array}{l}0 \\
0.0 \%\end{array}$ & 3.49 & $\begin{array}{l}9.35 \\
* *\end{array}$ & 0.00 \\
\hline $\begin{array}{l}\text { Up } \\
\text { Pal }\end{array}$ & $\begin{array}{l}\text { ating and Developing the } \\
\text { stinian Products }\end{array}$ & $\begin{array}{l}10 \\
2.6 \%\end{array}$ & $\begin{array}{l}77 \\
21 \%\end{array}$ & $\begin{array}{l}74 \\
19.6 \%\end{array}$ & $\begin{array}{l}197 \\
52.1 \%\end{array}$ & $\begin{array}{l}20 \\
5.3 \%\end{array}$ & 3.24 & $6.01 * *$ & 0.00 \\
\hline
\end{tabular}

** Significant at $0.01, *$ significant at 0.05 .

The Results of the Fifth Hypothesis

$\mathrm{H}_{\mathrm{O} 5}$ : The adopted policies and procedures by the Palestinian government have no competitive impact on the Israeli products.

Table 7 shows that updating and developing the Palestinian product has a positive impact on competing Israeli products. The mean of "updating and developing the Palestinian products" variable is 3.24 which indicates the that there is an impact of this variable on competing at the Israeli market. The value of $\mathrm{T}$ (one sample $\mathrm{t}$-test at test value $=3$ ) is 6.01 and statistically is significant. This result ensures that there is a positive role for updating and developing the Palestinian product on competing the Israeli product.

Table 7: Statistics for Describing the Impact of the Policies and Procedures of the Palestinian Government on Competing the Israeli Products

\begin{tabular}{|c|c|c|c|c|c|c|c|c|c|}
\hline \# & Question & $\begin{array}{l}\text { Strongly } \\
\text { Agree }\end{array}$ & Agree & Neutral & Disagree & $\begin{array}{l}\text { Strongly } \\
\text { Disagree }\end{array}$ & Mean & $\begin{array}{l}\mathrm{T} \\
\text { Value }\end{array}$ & Alpha \\
\hline 21 & $\begin{array}{l}\text { There is a government } \\
\text { support and facilities to } \\
\text { support the national } \\
\text { product. }\end{array}$ & $\begin{array}{l}27 \\
7.1 \%\end{array}$ & $\begin{array}{l}120 \\
31.7 \%\end{array}$ & $\begin{array}{l}110 \\
29.1 \%\end{array}$ & $\begin{array}{l}121 \\
32 \%\end{array}$ & $\begin{array}{l}0 \\
0.0 \%\end{array}$ & 2.60 & $-7.92 * *$ & 0.00 \\
\hline 22 & $\begin{array}{l}\text { There is control and } \\
\text { procedures against the } \\
\text { entry of the Israeli } \\
\text { products into the } \\
\text { Palestinian market. }\end{array}$ & $\begin{array}{l}27 \\
7.1 \%\end{array}$ & $\begin{array}{l}84 \\
22.2 \%\end{array}$ & $\begin{array}{l}79 \\
20.9 \%\end{array}$ & $\begin{array}{l}168 \\
44.4 \%\end{array}$ & $\begin{array}{l}20 \\
5.3 \%\end{array}$ & 2.50 & $-10.2 * *$ & 0.00 \\
\hline 23 & $\begin{array}{l}\text { There is cooperation and } \\
\text { coordination between the } \\
\text { Palestinian companies and } \\
\text { the decision makers. }\end{array}$ & $\begin{array}{l}79 \\
20.9 \%\end{array}$ & $\begin{array}{l}130 \\
34.4 \%\end{array}$ & $\begin{array}{l}38 \\
10.1 \%\end{array}$ & $\begin{array}{l}121 \\
32 \%\end{array}$ & $\begin{array}{l}10 \\
2.6 \%\end{array}$ & 2.31 & $-15.8^{* *}$ & 0.00 \\
\hline
\end{tabular}

www.jbrmr.com A Journal of the Centre for Business \& Economic Research (CBER) 


\begin{tabular}{|c|c|c|c|c|c|c|c|c|c|}
\hline 24 & $\begin{array}{l}\text { The Palestinian } \\
\text { government monitors the } \\
\text { company's quality } \\
\text { standards. }\end{array}$ & $\begin{array}{l}57 \\
15.1 \%\end{array}$ & $\begin{array}{l}131 \\
34.7 \%\end{array}$ & $\begin{array}{l}95 \\
25.1 \%\end{array}$ & $\begin{array}{l}85 \\
22.5 \%\end{array}$ & $\begin{array}{l}10 \\
2.6 \%\end{array}$ & 2.55 & -11.2 ** & 0.00 \\
\hline 25 & $\begin{array}{l}\text { There is a significant role } \\
\text { for the Palestinian } \\
\text { government in attracting } \\
\text { foreign investment to } \\
\text { strengthen the national } \\
\text { product. }\end{array}$ & $\begin{array}{l}57 \\
15.1 \%\end{array}$ & $\begin{array}{l}162 \\
42.9 \%\end{array}$ & $\begin{array}{l}68 \\
18 \%\end{array}$ & $\begin{array}{l}91 \\
24.1 \%\end{array}$ & $\begin{array}{l}0 \\
0.0 \%\end{array}$ & 2.23 & -21.1 ** & 0.00 \\
\hline \multicolumn{2}{|c|}{$\begin{array}{l}\text { Policies and Procedures of the } \\
\text { Palestinian Government }\end{array}$} & $\begin{array}{l}10 \\
2.6 \%\end{array}$ & $\begin{array}{l}77 \\
21 \%\end{array}$ & $\begin{array}{l}74 \\
19.6 \%\end{array}$ & $\begin{array}{l}197 \\
52.1 \%\end{array}$ & $\begin{array}{l}20 \\
5.3 \%\end{array}$ & 2.43 & $-16.9^{* *}$ & 0.00 \\
\hline
\end{tabular}

** Significant at $0.01,{ }^{*}$ significant at 0.05 .

The Results of the Sixth Hypothesis

$\mathrm{H}_{\mathrm{O} 6}$ : There is no impact of the follow-up and evaluation of Palestinian products on competing Israeli products.

Table 8 shows that updating and developing the Palestinian product has a positive impact on competing the Israeli product. The mean of "updating and developing the Palestinian products" variable is 3.24. This finding indicates the that there is an impact of this variable on competing at the Israeli market. The value of $\mathrm{T}$ (one sample t-test at test value $=3$ ) is 6.01 and statistically is significant. This result ensures that there is a positive role of updating and developing the Palestinian product on competing the Israeli product.

Table 8: Statistics for Describing the Follow-up and Evaluation of the Palestinian Products on Competing the Israeli Products

\begin{tabular}{|c|c|c|c|c|c|c|c|c|c|}
\hline$\#$ & Question & $\begin{array}{l}\text { Strongly } \\
\text { Agree }\end{array}$ & Agree & Neutral & Disagree & $\begin{array}{l}\text { Strongly } \\
\text { Disagree }\end{array}$ & Mean & $\mathrm{T}$ Value & Alpha \\
\hline 26 & $\begin{array}{l}\text { There is a continuous } \\
\text { monitoring and } \\
\text { evaluation of the } \\
\text { competitive situation } \\
\text { between Palestinian and } \\
\text { the Israeli companies. }\end{array}$ & $\begin{array}{l}27 \\
7.1 \%\end{array}$ & $\begin{array}{l}120 \\
31.7 \%\end{array}$ & $\begin{array}{l}110 \\
29.1 \%\end{array}$ & $\begin{array}{l}121 \\
32 \%\end{array}$ & $\begin{array}{l}0 \\
0.0 \%\end{array}$ & 2.69 & $-7.81 * *$ & 0.00 \\
\hline 27 & $\begin{array}{l}\text { The laws and procedures } \\
\text { shall be repealed, } \\
\text { amended to better serve } \\
\text { the interests of the } \\
\text { Palestinian companies. }\end{array}$ & $\begin{array}{l}27 \\
7.1 \%\end{array}$ & $\begin{array}{l}84 \\
22.2 \%\end{array}$ & $\begin{array}{l}79 \\
20.9 \%\end{array}$ & $\begin{array}{l}168 \\
44.4 \%\end{array}$ & $\begin{array}{l}20 \\
5.3 \%\end{array}$ & 2.50 & -12.4 ** & 0.00 \\
\hline 28 & $\begin{array}{l}\text { Studies are being } \\
\text { conducted on the } \\
\text { quantities and types of } \\
\text { Israeli products entering } \\
\text { Palestinian markets. }\end{array}$ & $\begin{array}{l}79 \\
20.9 \%\end{array}$ & $\begin{array}{l}130 \\
34.4 \%\end{array}$ & $\begin{array}{l}38 \\
10.1 \%\end{array}$ & $\begin{array}{l}121 \\
32 \%\end{array}$ & $\begin{array}{l}10 \\
2.6 \%\end{array}$ & 2.67 & $-7.49 * *$ & 0.00 \\
\hline 29 & $\begin{array}{l}\text { There is cooperation and } \\
\text { coordination among } \\
\text { Palestinian companies to } \\
\text { compete with Israeli } \\
\text { companies. }\end{array}$ & $\begin{array}{l}57 \\
15.1 \%\end{array}$ & $\begin{array}{l}131 \\
34.7 \%\end{array}$ & $\begin{array}{l}95 \\
25.1 \%\end{array}$ & $\begin{array}{l}85 \\
22.5 \%\end{array}$ & $\begin{array}{l}10 \\
2.6 \%\end{array}$ & 2.41 & -14.5 ** & 0.00 \\
\hline 30 & $\begin{array}{l}\text { The Palestinian } \\
\text { government and } \\
\text { Palestinian institutions } \\
\text { are developing plans to } \\
\text { make the Palestinian } \\
\text { product more } \\
\text { competitive. }\end{array}$ & $\begin{array}{l}57 \\
15.1 \%\end{array}$ & $\begin{array}{l}162 \\
42.9 \%\end{array}$ & $\begin{array}{l}68 \\
18 \%\end{array}$ & $\begin{array}{l}91 \\
24.1 \%\end{array}$ & $\begin{array}{l}0 \\
0.0 \%\end{array}$ & 2.22 & -19.4 ** & 0.00 \\
\hline \multicolumn{2}{|c|}{$\begin{array}{l}\text { Follow-up and Evaluation of } \\
\text { Palestinian Products }\end{array}$} & $\begin{array}{ll}10 \\
2.6 \%\end{array}$ & $\begin{array}{l}77 \\
21 \% \\
\end{array}$ & $\begin{array}{l}74 \\
19.6 \% \\
\end{array}$ & $\begin{array}{l}197 \\
52.1 \% \\
\end{array}$ & $\begin{array}{ll}20 \\
5.3 \%\end{array}$ & 2.49 & -18.1 ** & 0.00 \\
\hline
\end{tabular}

** Significant at $0.01,{ }^{*}$ significant at 0.05 .

\section{Conclusion and Recommendations}

This paper aims at examining the impact of six variables on competing the Israeli products at the Palestinian market. These variables are (competition for quality, corporate management practices, 
procedures and laws, update and development, government policies and procedures and follow-up and evaluation as well). The objectives of this paper match the conducted survey wherein the population consists of directors of organization, dealers, business owners, government employees, marketing managers, workers and customers. 500 questionnaires were distributed to the respondents in Palestine using the random sample. 378 questionnaires were returned which represent $75.6 \%$ of the distributed sample.

The findings of this paper are:

- The quality of Palestinian product has a positive competitive role against the Israeli product.

- There is a positive role of the Palestinian companies' administrative practices to compete the Israeli product.

- There is no role of the current Palestinian procedures and laws on competing the Israeli product.

- There is a positive role of updating and developing the Palestinian product to compete the Israeli product.

- There is a negative role of the policies and procedures of the Palestinian government on competing the Israeli product.

- The current practices of the follow-up and evaluation of the Palestinian products has a negative competing impact.

The abovementioned outcomes are consistent with the previous studies such as (Na'eem, 2017; AlNatshi, 2013; Hana, 2013). Also, this paper gave more finding about this topic.

Based on the previous findings, this paper suggests the following recommendations:

- The current Palestinian procedures and laws regarding the Palestinian competition should be developed to meet the requirements of competition. I suggest that the regulation should encourage the Palestinian consumer to select the local product (i.e tax deductions, discount ... etc.)

- The Palestinian government must reform its competition policies and procedures. This task should be implemented by the ministry of economics by preparing a set of studies and planning issues.

- The current practices of the follow-up and evaluation of Palestinian products should be updated. I mean evaluating the quality of Palestinian products and enforcing a set of procedures that increase the quality of these products and services,

- The Palestinian producer should increase the quality of the Palestinian products. The quality of local products should be consisted with Israeli products.

\section{References}

Amineh Al-Natshi. (2013). How to increase and diversify sources of direct Palestinian imports and reduce reliance on re-exported goods from Israel. Unpublished master thesis. Birziet University. Palestine.

Barney, J. B. (1991). Firm Resources and Sustained Competitive Advantage. Journal of Management Science. Volume 17. Issue 1. PP 99-120.

Dasgupta, A., Sahay, S. and Gupta, R. (2009). Technological Innovation and Role of Technology Strategy: Towards Development of a Model. 9th Global Conference on Business \& Economics.

Dyer, J. H. \& Singh, H. (1998). The relational view: cooperative strategy and resources of interorganizational competitive advantage. Academy of Management Review, 23(4), 660-679.

Hamel, G. and Green, B. (2007). The Future of Management. Boston: Harvard Business School Press.

Hana, U. (2013). Competitive Advantage Achievement through Innovation and Knowledge. Journal of Competitiveness. Volume 5. Issue 1. PP 82-96.

Najah Muslem .(2015) .The Palestinian Movement of Boycott, Divestment and Sanctions) BDS (as a Method of Nonviolent Resistance compared with South Africa's Boycott Movement. Birziet University. Palestine.

Petison, P., \& Johri, L. M. (2006). Driving harmony: philosophy of Toyota Motor Thailand. Strategic Direction. Volume 22. Issue 11. PP 3-5.

Romero, I. \& Martine-Roman, J. A. (2012). Self-employment and innovation. Exploring the determinants of innovative behavior in small business. Research Policy. Volume 41. Issue 1. PP 178-189.

Shapiro, C. (2012). Competition and Innovation: Did Arrow Hit the Bull's Eye?" in the Rate and Direction of Economic Activity Revisited, Josh Lerner and Scott Stern, eds. Chicago: University of Chicago Press. 
Švárová, M. and Vrchota, J. (2014). Influence of Competitive Advantage on Formulation Business Strategy. Procedia Economics and Finance. Volume 12,, Pages 687-694

Taber, S. (2018). The Use of Cronbach's Alpha When Developing and Reporting Research Instruments in Science Education. Education. Volume 48. Issue 6. PP 1273-1296.

Wafa Na, eem. (2017). The Role of Social Networks in Perspective the Palestinian Product from the Islamic University Students at the Gaza Strip " Case study: Food Industry 2016-2017". The Islamic University-Gaza.

Wen-Cheng, W., Chien-Hung, L., and Ying-Chien, C. (2011). Types of Competitive Advantage and Analysis. International Journal of Business and Management. Volume 6. Issue 5. PP 100-104. 